
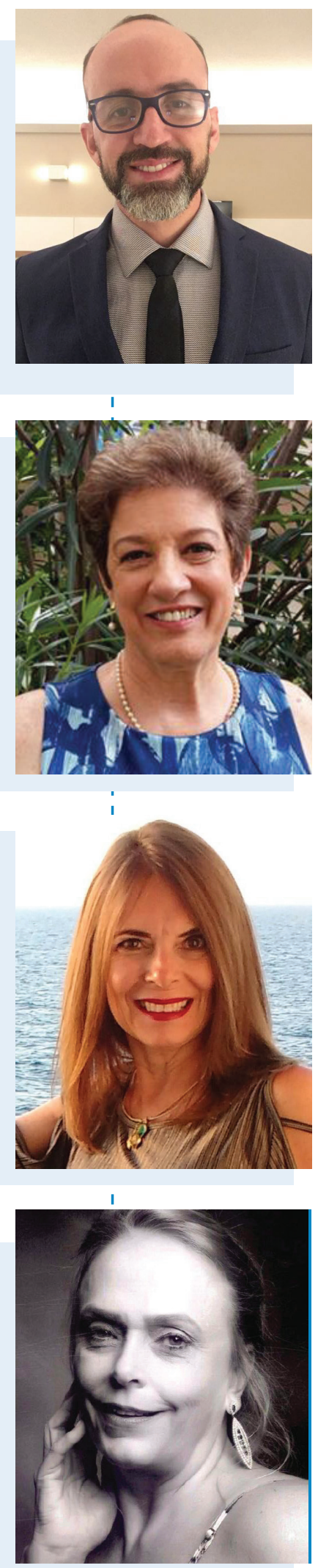

1

1. Universidade Federal de São João del-Rei/Campus Centro Oeste, Divinópolis (MG), Brasil

2.Universidade de São Paulo, São Paulo (SP), Brasil

3.Universidade de Campinas, Campinas (SP), Brasil

4.Universidade de Taubaté, Taubaté (SP), Brasil

*Autor correspondente: julianotmoraes@ufsj.edu.br
ORCID IDS

Moraes JT (D) https://orcid.org/0000-0002-1109-962X Santos VLCG (D) https://orcid.org/0000-0002-1288-5761 Dantas SRPE (D) https://orcid.org/0000-0002-9639-8900 Paula MAB (D) https://orcid.org/0000-0002-7438-9595 stomata, wounds and incontinence (urinary and anal) ${ }^{1,2}$. Brazi $^{4,5}$.

\title{
Accredited enterostomal therapy courses for excellence
}

\section{Cursos de estomaterapia acreditados para uma formação de excelência}

\section{Cursos de estomatoterapia acreditados para una formación de excelencia}

Juliano Teixeira Moraes', Vera Lúcia Conceição de Gouveia Santos²,
Sônia Regina Pérez Evangelista Dantas ${ }^{3}$, Maria Angela Boccara de Paula

\section{HOW TO CITE}

Moraes JT; Santos VLCG; Dantas SRPE; Paula MAB. Accredited enterostomal therapy courses for excellence. ESTIMA, Braz. J. Enterostomal Ther., 18: e0420 (2020). https:// doi.org/10.30886/estima.v18.866_IN

Until the end of the 1970s, enterostomal therapy could be practiced by other health professionals and even lay people. But soon after the creation of the World Council of Enterostomal Therapists (WCET ${ }^{\mathrm{TM}}$ ) in 1978, this became an exclusive specialty of nurses (from 1980 onwards) $)^{1,2}$.

The WCET ${ }^{\mathrm{TM}}$ is the official body of enterostomal therapy worldwide covering 55 countries at present. Its main purpose is the promotion of specialists and the normalization of the specialty worldwide, which has evolved to become an important component in the care of people with

In Brazil, enterostomal therapy was born on June 26, 1984, in the city of São Paulo/SP. The origin came from the creation of the Clinical Interest Group in Enteroestomatherapy Nursing (GICEE, Grupo de Interesse Clinico em Enfermagem em Enteroestomaterapia), later called the Group of Nursing in Enteroestomatherapy (GEE, Grupo de Enfermagem em Enteroestomaterapia) and the Group of Nursing in Enterostomal Therapy (GEEst, Grupo de Enfermagem em Estomaterapia), linked to the Commission of Education of the Brazilian Association of Nursing - Section São Paulo (ABEn - Section SP, Associação Brasileira de Enfermagem) ${ }^{3-5}$.

Still in the decade of 1980, some nurses looked for the specialized formation in the exterior, being one of them the nurse Gelse Mary Zerbeto, considered the first enterostomal therapist in

Soon after, in 1990, the 1st Specialization Course in Enterostomal Therapy Nursing was created at the Nursing School of the University of São Paulo (EEUSP, Enfermagem em Estomaterapia na 
Escola de Enfermagem da Universidade de São Paulo), under the responsibility of Prof. Dr. Vera Lúcia Conceição de Gouveia Santos. Since then, enterostomal therapy in Brazil has grown and strengthened more and more ${ }^{4,5}$.

With the expansion of the specialty, the Society was founded on December 4,1992, currently named as Brazilian Association of Enterostomal Therapy: Stomata, Wounds and Incontinences (Sobest ${ }^{\circledR}$, Associação Brasileira de Estomaterapia: Estomias, Feridas e Incontinências). It should be noted that Sobest ${ }^{\circledR}$ was one of the first nursing specialists to join the Brazilian Nursing Association (ABEn) $)^{4-6}$.

As provided in its statute, Sobest ${ }^{\circledR}$ has the following mission:

Technical and scientific development of its associates, the nursing community and health professionals aimed at assisting people with stomata, fistulas, tubes, drains, acute and chronic wounds and anal and urinary incontinence, in their preventive, therapeutic and rehabilitation aspects, aiming at improving the quality of life $^{7}$.

Guided by this premise, Sobest ${ }^{\circledR}$ is the only official organ of enterostomal therapy in Brazil, since its foundation. The association with the WCET ${ }^{\mathrm{TM}}$ occurred in 1992, thanks to the first international delegate from Brazil, Prof. Dr. Vera Lúcia Conceição de Gouveia Santos.

With regard to specialist training for enterostomal therapist nurses, Sobest ${ }^{\circledR}$ follows the international recommendations of WCET ${ }^{\mathrm{TM}}$. It is worth noting that, until 2011, the courses in Brazil were undergoing an evaluation process conducted by WCET ${ }^{\mathrm{TM}}$ to obtain recognition by the council ${ }^{8}$. Such a process was costly, as well as time consuming. Until then, the educational institution should provide for the costs of translation into English and submission of documents. In addition, the course was also submitted to evaluation by reviewers of the Board of Education of Sobest ${ }^{\circledR}$, leading to overlapping work of its board in Brazil.

In 2011, the WCET $^{\mathrm{TM}}$ granted the Memorandum of Understanding (MOU) to Sobest ${ }^{\circledR}$ during the IX Brazilian Enterostomal Therapy Congress. This MOU allowed Sobest ${ }^{\circledR}$ to analyze the documents of the enterostomal therapy courses in the country, accrediting them nationally and internationally on behalf of WCET ${ }^{\mathrm{TM}}$. Brazil was the first country to formally receive the MOU. Before our country, only the United States was exempted from the analysis of its programs for accreditation with WCET ${ }^{\mathrm{TM}}$. By 2020, only six countries are qualified for this assessment: United States, Brazil, Germany, France, Australia and Hong Kong.

Since then, Sobest ${ }^{\circledR}$ receives proposals for new courses, advises on the adequacy of existing courses to the international guidelines of $\mathrm{WCET}^{\mathrm{TM}}$, evaluates the quality of the courses through theoretical and practical indicators, conducts visits to institutions and fields of practice and enables the course to the recognition of WCET ${ }^{\mathrm{TM}}$. These activities are currently performed by the Department of Education of Sobest ${ }^{\circledR}$.

Certainly, the accreditation of Sobest ${ }^{\circledR}$ through WCET ${ }^{\mathrm{TM}}$ MOU, besides the increasing visibility of the specialty, was one of the contributing factors to the exponential increase in the offer of enterostomal therapy courses in recent years (Fig. 1).

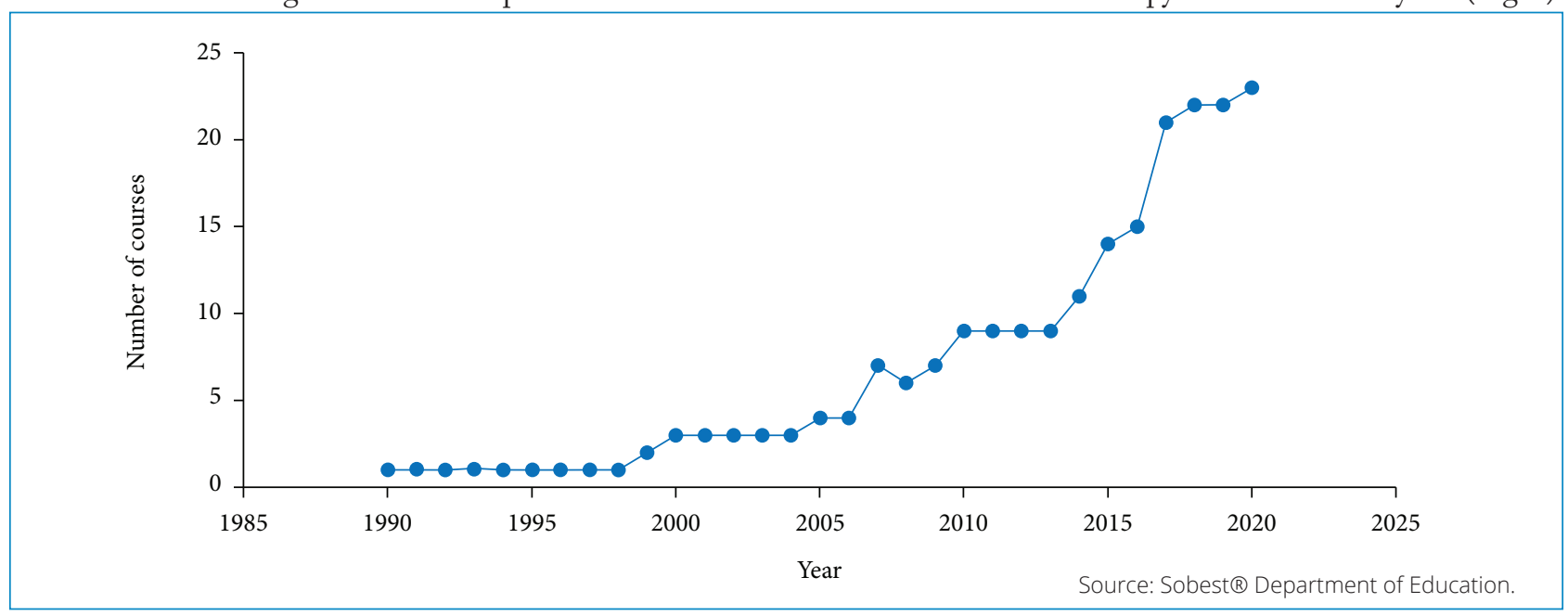

Figure 1. Number of enterostomal therapy nursing courses accredited by Sobest $\circledast$ in Brazil. 
The postgraduate courses in enterostomal therapy nursing recognized by Sobest ${ }^{\circledR}$ are of high performance, with equitable theoretical and practical workloads and involve the three paradigmatic areas in Brazil: stomata, wounds and incontinence. All courses have an important focus on topics related to professional development and the continuous learning of participants.

In addition to the lato sensu postgraduate certificate issued by the higher education institution accredited by the Ministry of Education, the graduates of these courses receive a nominal certificate from WCET ${ }^{\mathrm{TM}}$ with international recognition, this certificate makes it easier to work as an enterostomal therapist outside the country.

Considering the trajectory of enterostomal therapy and postgraduate courses in enterostomal therapy in Brazil, Sobest ${ }^{\circledR}$ launched the concept of "accredited enterostomal therapy courses" (Fig. 2). Accreditation is a legally secure concept to define the role of the association in relation to the courses that pursue such quality certification. According to the Portuguese language dictionary ${ }^{9}$, accreditation is the official recognition of a person or entity for the performance or accomplishment of something. In this process, Sobest ${ }^{\circledR}$ therefore recognizes an entity (course) for the performance (training) of something (enterostomal therapy). Sobest ${ }^{\circledR}$ "believes" or "gives credit" to any postgraduate course in enterostomal therapy nursing that voluntarily pursues such certification. Accreditation implies that the course meets all the essential criteria and requirements for the training of the enterostomal therapists according to WCET ${ }^{\mathrm{TM}}$ guidelines and Sobest ${ }^{\circledR}$ itself.

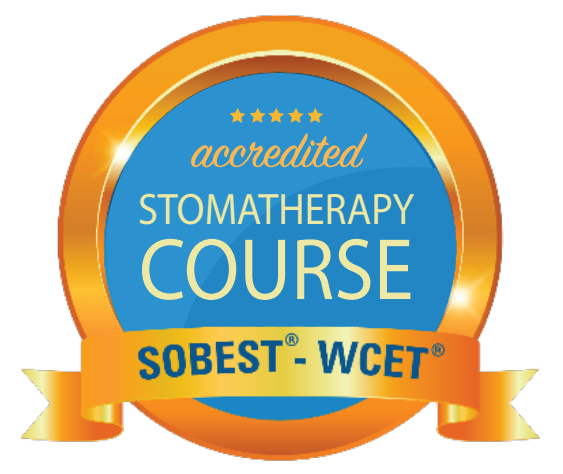

Figure 2. Quality seal assigned to courses accredited by Sobest ${ }^{\circledR}$.

It is important to emphasize that, in Brazil, in addition to the educational norms in force established by the Ministry of Education and the National Council of Education related to the authorization of lato sensu postgraduate courses ${ }^{10}$, and the resolutions of the Federal Nursing Council for the registration of nursing specialists11, the accreditation Sobest ${ }^{\circledR /}$ WCET $^{\mathrm{TM}}$ provides a certificate that the course is equivalent to international training and that it has quality validated by a serious institution committed to professional ethics.

The specialty is expected to grow even more in Brazil, covering all the states and regions of a country of continental dimensions. With the accreditation of the courses in force since the late 1990s, progress will be made in proposing public health policies and offering highly qualified professionals for the health care of people with stomata, wounds or incontinence.

\section{REFERENCES}

1. Stelton S. The WCET at 40. Adv Skin Wound Care. 2018;31(4):150-1. https://doi.org/10.1097/01.ASW.0000531296.56431.c1

2. World Council of Enterostomal Therapists (WCET). WCET history. Washington: WCET, 2020. [cited on 26 mar 2020 ]. Available at: https://www.wcetn.org/history 
3. Yamada BFA, Rogenski NMB, Oliveira PA. Aspectos históricos, éticos e legais da estomaterapia. ESTIMA, Braz. J. Enterostomal Ther. $2003 ; 1(2)$.

4. Thuler SR, Paula MAB, Silveira NIS. SOBEST: 20 anos. Campinas: Arte Escrita, 2012.

5. Santos VLCG, Cesaretti IUR. Assistência em estomaterapia: cuidando de pessoas com estomia. Rio de Janeiro: Atheneu, 2015.

6. Paula MAB, Paula PR, Cesaretti IUR. Estomaterapia em foco e o cuidado especializado. São Caetano do Sul: Yendis Editora, 2014.

7. Associação Brasileira de Estomaterapia (SOBEST). Estatuto. São Paulo: SOBEST, 2014. [cited on 26 mar 2020]. Available at: http:// www.sobest.com.br/arquivos/estatuto.pdf

8. World Council of Enterostomal Therapists (WCET). ETNEP/REP recognition process guidelines. Washington: WCET, 2017 . [cited on 26 mar 2020]. Available at: https://www.wcetn.org/assets/Education/ETNEP-REP/ETNEP\%20REP\%20Guidelines\%20Dec\%202017.pdf

9. Ferreira ABH. Dicionário Aurélio da Língua Portuguesa. 5ed. Curitiba: Positivo, 2014.

10. Ministério da Educação (Brasil). Resolução CNE/CES 1/2018, de 6 de abril de 2018: Estabelece diretrizes e normas para a oferta dos cursos de pós-graduação lato sensu denominados cursos de especialização, no âmbito do Sistema Federal de Educação Superior, conforme prevê o Art. 39, § 3º da Lei n 9.394/1996, e dá outras providências. Brasília: Diário Oficial da União 9 de abril de 2018, Seção 1, p. 43.

11. Conselho Federal de Enfermagem (COFEN). Resolução n 581, de 11 de julho de 2018: Atualiza, no âmbito do sistema Cofen/ Conselhos Regionais de Enfermagem, os procedimentos para registro de títulos de pós-graduação lato e stricto sensu concedido a enfermeiros e aprova a lista das especialidades. Brasília: Diário Oficial da União 18 de julho de 2018, Seção 1, p. 119. 